\title{
Scenario of Employee Welfare Programs in IT sector of Rajasthan - Employee Expectations and Reality
}

\author{
Dr. Manju Nair \\ Principal, ISIM Jaipur \\ Swati Jha \\ Research Scholar, Rajasthan Technical University
}

\begin{abstract}
Employee Welfare is a corporate attitude or commitment reflected in the expressed care for employees at all levels. The term welfare suggests the state of well-being, health, happiness, prosperity and the development of human resources. The present study is an attempt to identify the employee welfare programs being conducted in IT industry and analysing the satisfaction level of employees from these activities. The study also aims at finding out how aware employees are regarding the basic welfare activities that they are entitled to avail at workplace. The effective and efficient policies and welfare facilities (statutory and non statutory) make the employee to perform the job better, which leads to effectiveness of the organization and is a factor of employee engagement. As a major outcome of the study, the organisations focus differently on the various Employee Welfare Programs on the basis of the need and priorities of the employees. The research tool used for primary data collection was structured questionnaire and personal interviews. Secondary data was taken through various journals, magazines and company websites. Out of 240 questionnaires rotated 200 were received with proper responses that were analysed and conclusions were drawn. The data was collected through employees and HR managers of various IT and ITes companies of the state of Rajasthan.
\end{abstract}

Keywords- Employee Welfare Programs, Employee Engagement, IT and ITeS, HR practices , statutory and Non Statutory.

\section{Introduction}

The contribution of the human resource management in the overall functioning and performance of an organisation has gone through transformational changes. Starting from labour officer, personnel officer, personnel manager to the current human resource manager, the change in the title very well reflects the expanding horizon of functions and objectives. In today's ultracompetitive business environment, the thing that an organisation focuses on the most is its Human resource. The golden rule of happy employees = happy customers has been tried and tested by giants of different industries worldwide. A well engaged happy employee provides competitive edge to the organisation.

The importance of engaged workforce that is committed to its role, aims at providing best results and which draws maximum satisfaction and contentment from their work, is the ultimate goal of each and every organisation. Sustainable growth of firms is dependent not only on short term benefits but also strong welfare programs that actively engages the employees'. Only when an employee feels cared and aligns his personal growth with the company's growth, the optimum level of productivity in terms of efficiency and effectiveness is achieved.

In the current boundary less world various multinational companies have started their operations in India. Out of all, IT sector is the one that has achieved the highest level of international exposure in terms of trade and knowledge exchange. HR professionals worldwide are adopting successful strategies in their organisations to gain maximum level of engagement possible. Engagement can be directly linked with the state of psychological, social, physical and financial well being of an employee.

A happy and content employee who feels valued and appreciated in different terms can provide better results .The organisations are going beyond the benchmarks for providing best Employee Welfare Programs .But due to the cut throat competition, the employees are at times devoid of the minimum bare welfare programs that are not a luxury but a necessity for them. To safeguard the basic rights of the employees the Government of India has laid down many laws, most importantly the labour laws that are applicable to all the organisations across all the sectors. ILO (International Labour Organisation) has divided the various welfare practices into two broad categories namely Statutory and Non Statutory welfare programs.

Statutory Welfare Programs- Statutory refers to the basic welfare programs that are mandated by government. Statutory Welfare programs include all the amenities provided in or near the organization and related to the working and living conditions like - Drinking Water , Facilities for sitting ,First aid appliances ,Urinals ,Canteen facilities ,Lighting, Washing places ,Changing rooms ,Rest rooms etc .

Non statutory refers to those that are not mandated by law, but are provided in order to engage employees; these refer to those measures that aim at promoting physical, psychological and general well being of 
the working class. For the ease of analysis and better understanding the researcher has divided the Non statutory welfare programs into 7 sub categories namely-

1. Financial welfare program

2. Health welfare program

3. Career welfare program

4. Psychological welfare program

5. Spiritual welfare program

6. Social welfare program

7. Family welfare program

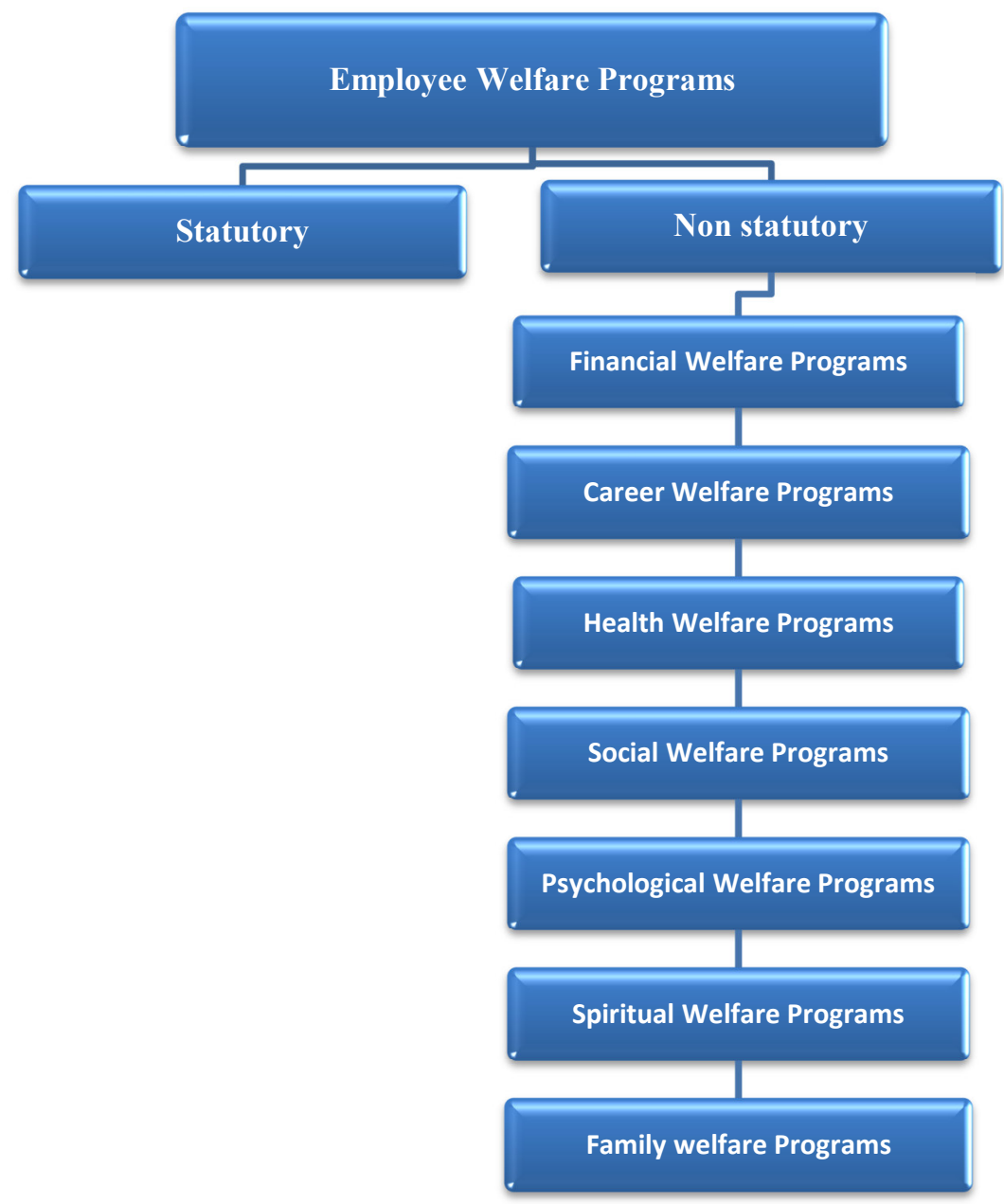

Classification for Employee Welfare Programs

On the basis of the need and priorities of the employees, the organisations focus differently on the various Employee Welfare Programs.

\section{Review of literature}

Incentives, rewards and recognition are the key parameters of today's incentive programs according to most of the Organizations. Employee welfare is a wide-ranging term including various services benefits and facilitates presented to employees by employer. The face of EWP has changed many folds. With the advancing technology and competition a strong Employee Friendly policy is very much essential.

Coventry and Barker (1988) assert that employee welfare includes providing staff and workers' canteens, providing savings schemes; pension funds and leave grants, making loans on hardship cases; providing assistance to staff transferred to another area and providing fringe benefits and other basic facilities. Job satisfaction is generally recognized as an all-round construct that includes employee feelings about a variety of both essential and non essential job elements.

It encompasses specific aspects of satisfaction related to pay, benefits, promotion, work conditions, supervision, organizational practices and relationships with co-workers (Misener et al., 1996). Productivity, on 
the other hand, means goods and services produced in a specified period of time in relation to the resources utilized (Singh, 2009). Thereby, factors like incentives, rewards and welfare are the most preferred factors for employee engagement programs.

Corporate cultures characterized by team working, pleasing working conditions, thoughtful treatment of employees, development opportunities, flexible-working practices, and good leadership and management practices promote employee engagement. This can happen only when employees are ardent and happy about their job. They are cognitively, psychologically and emotionally linked to the organization and the job they are dealing with or assigned for.

Joseph et.al.(2009) points out that the structure of a wellbeing state depends on the fabric of its social security. Government, employers and trade unions have done a lot to promote the betterment of worker's living conditions

Sabarirajan et.al.(2010) in his study throws light on the impact of welfare measures on QWL among the employees of textile mills in Salem district ,shows that $15 \%$ of the employees are highly satisfied with their welfare measures. $22 \%$ of the employees are satisfied with their welfare measures.39\% of the employees was having average satisfaction with their welfare measures. $16 \%$ of them are at high dissatisfaction level. He concluded that Welfare measures plays important role in employee fulfilment and it results in improved quality of work life.

Satyanarayna and Reddi (2012) stated that the overall contentment levels of employees about welfare measures in the organization is satisfactory. However, a few are not satisfied with welfare measures provided by the organization. Therefore it is suggested that the existing welfare measures may be improved further. Such welfare measures enlarge the employee standard of living and their satisfaction levels.

Sindhu (2012) stated the employee welfare measures increase the efficiency of organization and support healthy industrial relations making a positive work environment . Organizations provide welfare services to their employees to keep their encouragement levels high. Business houses provide many such statutory and non statutory welfare policies to maintain satisfactory level of their employee engagemen and job and organizational commitment.

When they get better canteen facilities, good quality water to drink, clean restrooms, clean and hygienic washrooms and bathrooms, regular medical checkups, health insurance, Employee assistance programmes, grievance handling department, ergonomically designed sitting or good work place gives employee a high level of satisfaction. This boosts an organisation to grow much faster.

Upadhyay and Gupta (2012) conclude that well laid out communication plays a major role in increasing the satisfaction level of an employee. Satisfied employees are reported to have high morale. Welfare measures and work experience does not necessarily relates to satisfaction. Therefore its recommended that company should provide for adequate welfare measures but should not lumber itself.

Mohan and Panwar (2013) show the retail stores at Udaipur are providing not only intramural facilities but also extramural welfare facilities. It is going overboard its hands to provide amenities that may improve health and living standards of the employees. The effective and efficient policies and welfare facilities make the employee to perform their job better, which leads to effectiveness of the organization.

Resma and Basavraju (2013) stated the employee welfare is a comprehensive term including various services, benefits and facilities offered to employees of the organization by the free will of employer. This study enlightens the concept of welfare measures; it also highlights the employee's perception regarding the various statutory welfare measures provided by the Donimalai Iron Ore Mine, Bellary.

Logasakthi and Rajagopal (2013) revealed that the employees enjoy not only the satisfaction of their jobs but also various facilities given by the firms. The employees extend their utmost support for the improvement of the organisation. The personal department takes care of the total human resources management in the company. The management provides all the health and safety welfare measures to the employees that will help to produce better performance in the work and working environment.

Srinivas(2013) identified welfare facilities and employee's satisfaction level about welfare facilities adopted at Bosch limited, Bangalore. It was found that most of the, statutory welfare facilities like medical room, canteen, working environment, safety measures etc., are provided by the company and most of the employees are satisfied with the welfare facilities adopted by the company towards the employee's welfare.

Nanda and Panda (2013) stated that, Rourkela Steel Plant has adopted a better kind of welfare activities which create an effective working environment and thus pertains to better productivity and performance. There are different kind of welfare schemes like, insurance, housing medical allowance; death relief fund and transportation facilities recreation club etc. That are provided by the company to the employees to maintain the industrial relation .

\section{Objectives of the study}

1. To analyse the various Employee welfare programs (EWP) provided in the IT sector in Rajasthan 
2. To find out which type of Employee welfare program is most preferred by the employees.

3. To investigate the satisfaction level of employees from Employee welfare Programs being provided.

4. To find out the awareness level of employees regarding the statutory welfare programs.

5. To make valuable suggestions regarding the EWP that employees want to be incorporated in their organisations to bridge the gap between expectations and reality

\section{Research Methodology}

1. Universe of the study

The IT sector is divided into 4 major categories

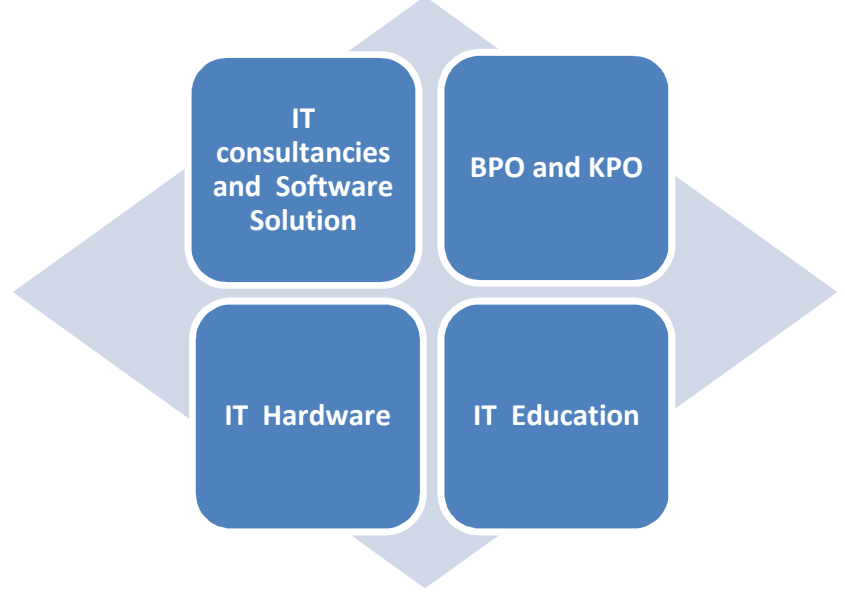

\section{Classification of IT sector}

2. Sample of the study

Out of these four categories the researcher focused on first two that IT consultancy and software solutions and BPO and KPO's. The reason for this filtration is - IT education and IT hardware are very small and family run firms basically with a very small workforce, hence they doesn't have many welfare practices for their employees. In Rajasthan there are many BPO and KPO'S and numerous big and small It consultancies and software solution firms. Out of these only the companies having greater than 50 employees were taken as a sample. The reason being, only the companies having more than 50 employees are liable to provide all the statutory benefits to the employees.

Sample size is 200. It includes the employees and HR personnel's of major BPO's \& KPO's and IT and ITeS companies.

3. Data collection

The study analyses the various Employee welfare Programs provided at major IT and ITES companies of Rajasthan. The Primary data was collected through two modes

I. Questionnaire that finds out the status of the various Non Statutory welfare programs provided to them as well as what are the expectations of the employees from the employer that could help to improve their effectively and efficiency towards work.

II. Interview of the HR managers to find out the various kinds of Employee Welfare Programs being provided to Employees.

Secondary data was collected through E- journals, Company websites, magazines and articles.

\section{Relevance of the study}

As an outcome of this study, the researcher here exhibit the various types of Employee welfare programs that are being provided to the employees working in IT sector of Rajasthan. It also collects the information regarding the suggestions of the employees towards improving the status of these EWP as well as implementation of new programs in their organisations. The research presents a clear scenario of the prevalent Employee welfare programs. It highlights the gap between what is provided to the employees and what actually they want.

It also gives a clear picture of the extent of concern that these companies have towards their employee's .And hence indicating the initiatives of various organisations in lieu of mental, financial, social, physical and psychological welfare of their employees.

\section{Findings and conclusion}

Objective 1. To analyse the various Employee welfare programs (EWP) provided in the IT sector in Rajasthan A friendly working environment, special healthcare facilities, flexible work hours, work from home options, women-friendly policies and support among the team members keep employees highly motivated. Various 
reward and recognition programs ensure that innovation, creativity, leadership and team work is rewarded along with individual contributions. Fast track growth paths are created for high performers. Parenting, relationship counselling, child psychology workshops help build a bond with families of employees

With a strong focus on employee's health and overall well-being, lifestyle assessment checks, dental/medical/eye checkups, life-skill workshops, stress management through yoga, meditation, panic healing, check-up camps, physiotherapy are undertaken.

Below are categorically listed some most important and preferred Employee welfare programs-

\section{Financial assistance programs}

- Performance based incentives and bonuses at the end of financial year. Incentives are provided for outstanding performances by the employees. Yearly bonuses are also distributed in order to keep the employees motivated.

- Zero percent interest on loans provided to employees (short term and long term)- Some organisations have this facility of taking loans from the organisation at zero interest rates and the loan can be paid by the employees via deductions from the salary over a period of time.

- Advance salary schemes- In case of any emergency condition employees can apply for advance salary schemes .The organisation provides the salary on the basis of the severity of the condition and conduct and tenure of the employee in the organisation.

- Flexible Salary Benefits: Its main objective is to provide flexibility to the employees to plan a taxeffective compensation structure by balancing the monthly net income, yearly benefits and income tax payable. It is applicable of all the employees of the organization. The Salary consists of Basic, DA and Conveyance Allowance. The Flexible Benefit Plan consists of: House Rent Allowance, Leave Travel Assistance, Medical Reimbursement, and Special Allowance.

- Educational Benefits: Many companies have this policy to develop the personality and knowledge level of their employees and hence reimburse the expenses incurred towards tuition fees, examination fees, and purchase of books subject, for pursuing MBA, and/or other management qualification at India's top most Business Schools.

- Cellular Phone / Laptop: Cellular phone and / or Laptop are provided to the employees on the basis of business need. The employee is responsible for the maintenance and safeguarding of the asset.

- Company Leased housing: Some of the companies provides shared accommodation for out station employees, in fact some of the BPO companies also undertakes to pay electricity/water bills as well as the Society charges for the shared accommodation. The purpose is to provide to the employees to lead a more comfortable work life balance.

- Corporate Credit Card: The main purpose of the corporate credit card is enable the timely and efficient payment of official expenses which the employees undertake for purposes such as travel related expenses like Hotel bills, Air tickets etc .

- Subsidized Food and Transportation: The organizations provide transportation facility to all the employees from home till office at subsidized rates. The lunch provided is also subsidized.

\section{Health wellness programs}

- Personal Health Care (Regular medical check-ups): Some of the companies provide the facility for extensive health check-up. Some of the BPO'S provides the facility for extensive health check-up. For employees with above 40 years of age, the medical check-up can be done once a year.

- Medi-claim Insurance Scheme: This insurance scheme provides adequate insurance coverage of employees for expenses related to hospitalization due to illness, disease or injury or pregnancy. Some big organisations provide family insurance too that covers the whole family or any dependents on the employee.

- Yoga, Aerobics and gyms are set up at the campus. It helps employees to save the time going to the gyms. They might come early or workout after the working hours. The membership fees of these gyms are either subsidised or free for employees. Small organisations have tie ups with gyms near their office for discounted memberships.

- $\quad$ Sports activities for recreation for eg- cricket, football, tennis matches etc are organised every now and then for keeping the employees active and competitive. These matches are organised among different departmental teams, with other organisations and colleges etc. Employees are provided with sports gear and funds for these matches.

- In case of any fatality or medical condition the organisations provide advance salary, collects funds for the employee and provide extensive financial support(though there is no written rule for the same , the financial aid totally depends upon your working tenure in the organisation). 
- The organisations nowadays are paying extra attention to create ergonomically designed workstations. Keeping in view the health wellness of the employees furniture, work set up, space between the cubicles, proper hardware for best ease etc are few things that organisations invest their time and money in.

\section{Career welfare programs}

- Flexi-time: The main objective of the flexi- time policy is to provide opportunity to employees to work with flexible working schedules.

- Trainings for further skill enhancement that are sponsored by the employer. Companies pay fully or partially for skill enhancement trainings. These training helps the employees stay equipped with the new things happening in their fields.

- Regular training schedules and short term courses- Every now and then employees go through in-house training schedules in their fields in order to keep them updated and well trained.

- Job rotation and Job enlargement for holistic development- every organisation wants its employees to multitask .This has a two way benefit. Firstly the employees get hands on experience of every field which expands the horizon of their work, Secondly; it helps organisations to manage work in case of leave and absenteeism of any employee.

- Employee Referral Scheme: In several companies employee referral scheme is implemented to encourage employees to refer friends and relatives for employment in the organization. Some organisations even provide incentives to the employees if their referred friends provide good results.

- The organisations that are located at multiple locations or multiple countries send their employees for onsite work projects to different countries. Employee exchange programs from different offices in different countries help in providing the much required exposure to the employees for different business practices.

- In case the employees are sent to any offshore location than they are counselled and guided properly by their mentors throughout the process of their working and adjusting at a new location.

- Various awards and recognition programs like "Employee of the month" etc helps the employees to prove their credibility in their further assignments with the same or different organisation.

\section{Psychological wellness programs}

- Employee Assistance Programs: Various assistant programs are arranged like external counselling service so that employees or members of their immediate family can get counselling on various matters.

- Harassment Policy: To protect an employee from harassments of any kind, guidelines are provided for proper action and also for protecting the aggrieved employee. A strong watch is kept for any cases of bullying or harassment of any sort at work place.

- Mentor Mentee schemes for proper guidance. Mentors are responsible for on the job training of employees. Employees can go and consult with their mentor in case of any issue arising out of work. Usually mentors are immediate seniors .Mentors are also responsible for performance of their employees .They monitor their work, Behaviour, interaction with colleagues etc and hence can rectify any activity that is uncalled for.

- Complaint boxes - many organisations have this system of complaint boxes that are located at common places in the office. These boxes are locked and can be opened by HR department only. In case any employee has any complaint that he likes to bring into the notice of management without coming into limelight than he can drop off his complaint in these boxes in total anonymity. These boxes are checked every 15 days and after thorough discussion and analysis appropriate complaints are brought into notice of top management for any kind of action to be taken upon them.

- Employee grievance redressal cells and committees - Many organisations have a proper grievance redressel committee for resolving any issues among employees. These committees work with total impartiality without any biases for proper psychological support of employees.

- Women safety initiatives- women safety initiatives are very much at priority at various organisations. For women employee's safety pick and drop for employees working in night shifts are provided by the organisation. These pick and drops are video monitored and have special safety features. Any case of sexual harassment can be directly reported to the top management and is resolved by a committee having at least one third women members.

- Flexi-time: The main objective of the flexitime policy is to provide opportunity to employees to work with flexible work schedules and set out conditions for availing this provision. Flexible work schedules are initiated by employees and approved by management to meet business commitments while supporting employee personal life needs. The factors on which Flexi time is allowed to an employee 
include: Child or Parent care, Health situation, Maternity, Formal education program .

\section{Family welfare programs}

- Maternity \& Adoption Leave - Employees can avail maternity or adoption leaves in case of need showing all the medical records required for the same. Every registered organisation is liable to give three months of maternity and one month of paternity leave to the employees.

- Paternity leave policies have also been introduced by various companies.

- Family day and Family outings organised by employers- Once in a year the organisations organise events for families of the employees. The initiative helps the family connect to the organisations. Mostly the founding day of the organisations are celebrated.

- On occasions like children's day, certain organisation allow employees to bring in their children to the office and organises various events for them.

- Family insurance- the dependent family members are provided insurance cover .Any medical expenses on the family of the employees are covered under that scheme.

- Crèches and pet care centres at some organisations.

- Wedding, Birthday and anniversary gifts to the employees.

\section{Spiritual wellness programs}

- Construction of temples in the premises.

- Certain organisations provide prayer room for employees and short break to complete their religious obligations.

- $\quad$ All the major festivals are celebrated at the campuses and gifts are distributed to the employees.

- Yoga and meditation centres for relaxation and rejuvenation, reduced working hour on days of spiritual importance.

- Celebrating various festivals \& organizing competitions on the festivals with families of employees.

\section{Social welfare program}

- Corporate social responsibility initiatives are taken in the form of tree plantation drives, Blood donation camps, visits to orphanage and old age homes, street plays to spread social awareness, charity shows etc.

- Short breaks and informal meetings to create bonding among employees which facilitate development of interpersonal skills.

- Tie ups with various NGO's that motivates employees to join them for various social activities.

Objective 2. To find out which type of Employee welfare program is most preferred by the employees.

On the basis of the data received out of all the Employee Welfare Programs Financial Welfare Programs and career Welfare Programs works best when it comes to preference of Employees. Most of the employees look out for these when they consider any job opportunity. Also these are the factors that make them more satisfied and engaged in their jobs.

Social and Spiritual welfare Programs were least preferred by Employees. 


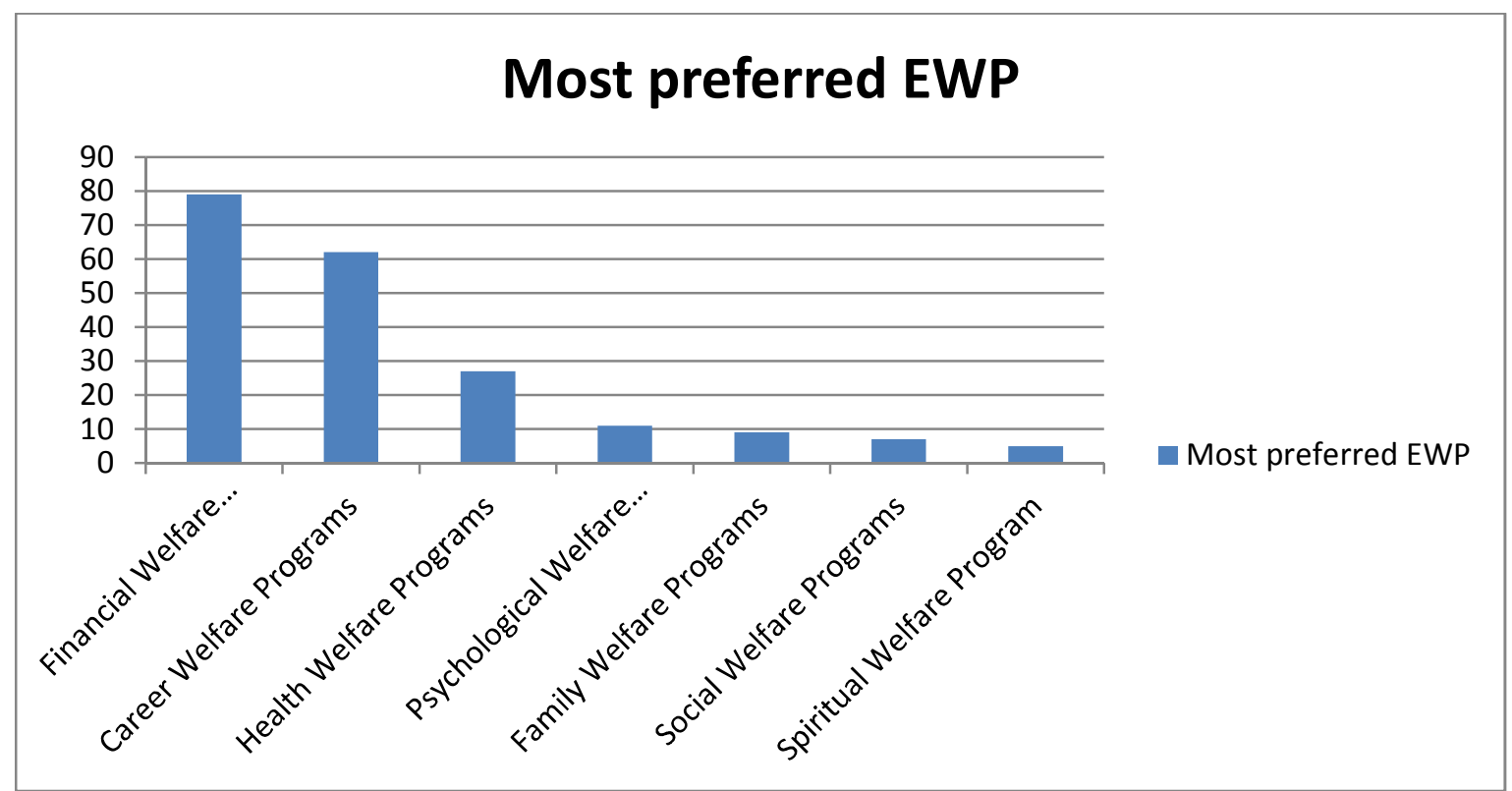

Objective 3. To investigate the satisfaction level of employees from Employee welfare Programs being provided.

The satisfaction level of employees was measured on different parameters .the results are as follows-

a) On the basis of Gender - Men tend to be more satisfied with EWP as compared to their female counterparts.

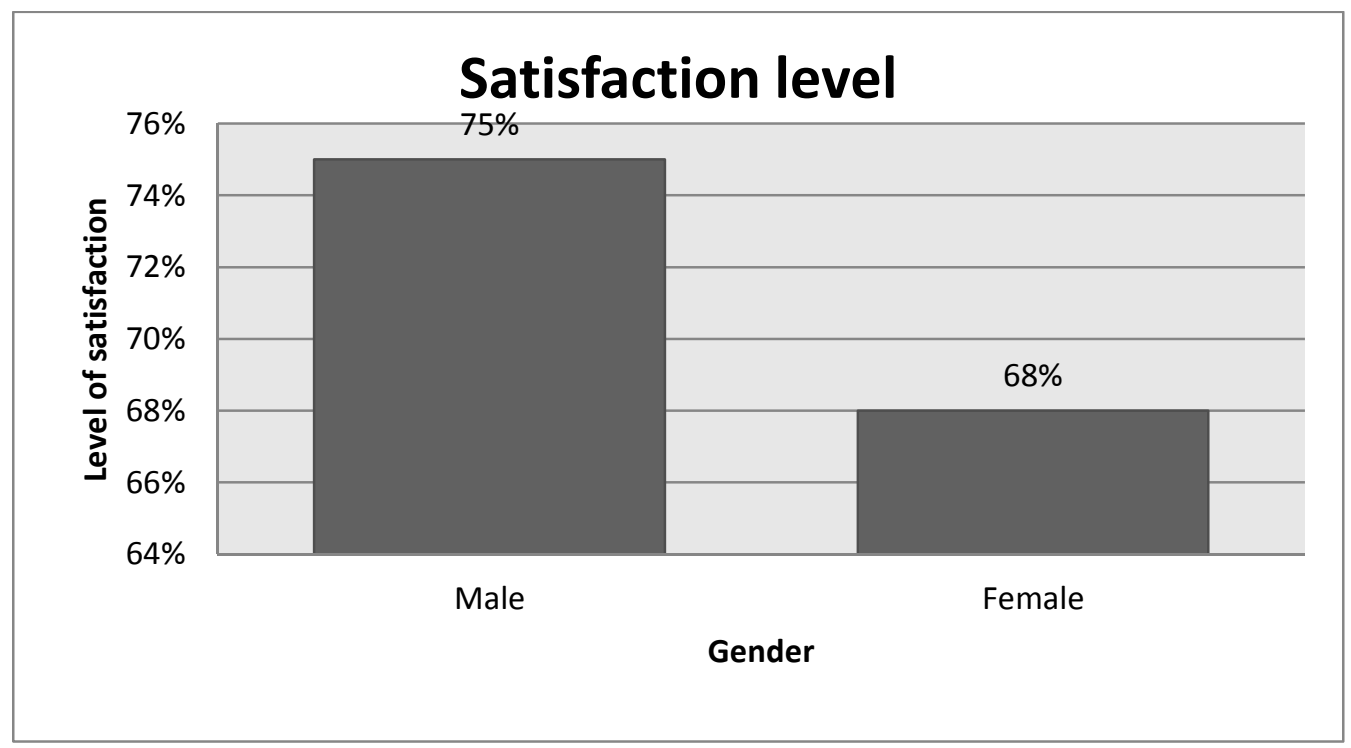

b) On the basis of Age -

Employees in the age group of 31 to 40 years are most satisfied. Whereas employees in age group of 20-30 yrs and 40 yrs and above are mostly dissatisfied. 


\section{\% Level of satisfaction}

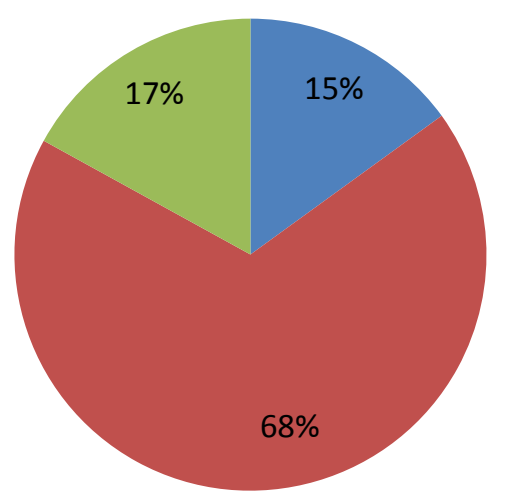

20-30 years

- 31 - 40 years

41 years and more

c) On the basis of tenure in organisation

With the advancing tenure in an organization the level of satisfaction improves. But if an employee continues for a longer duration in an organisation he tends to get dissatisfied after a while. The prospective reason is increasing expectations of employees from employer as he gains seniority.

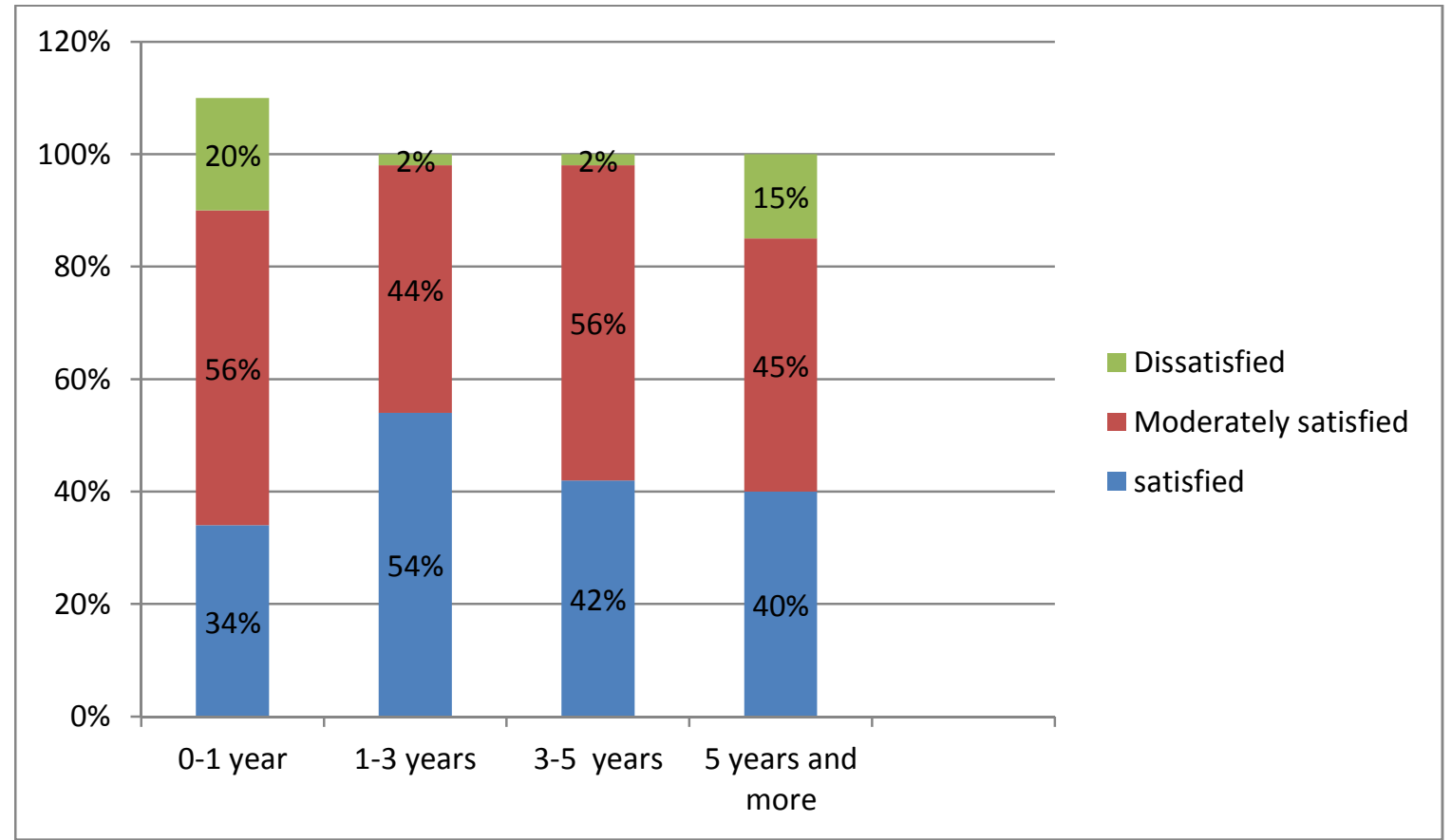

\section{Level of Satisfaction}

Objective 4- Awareness level of employees regarding the statutory welfare programs

a) On the basis of Gender - Males are more aware about Statutory Welfare Programs as compared to Females. 


\section{\% level of Awareness}

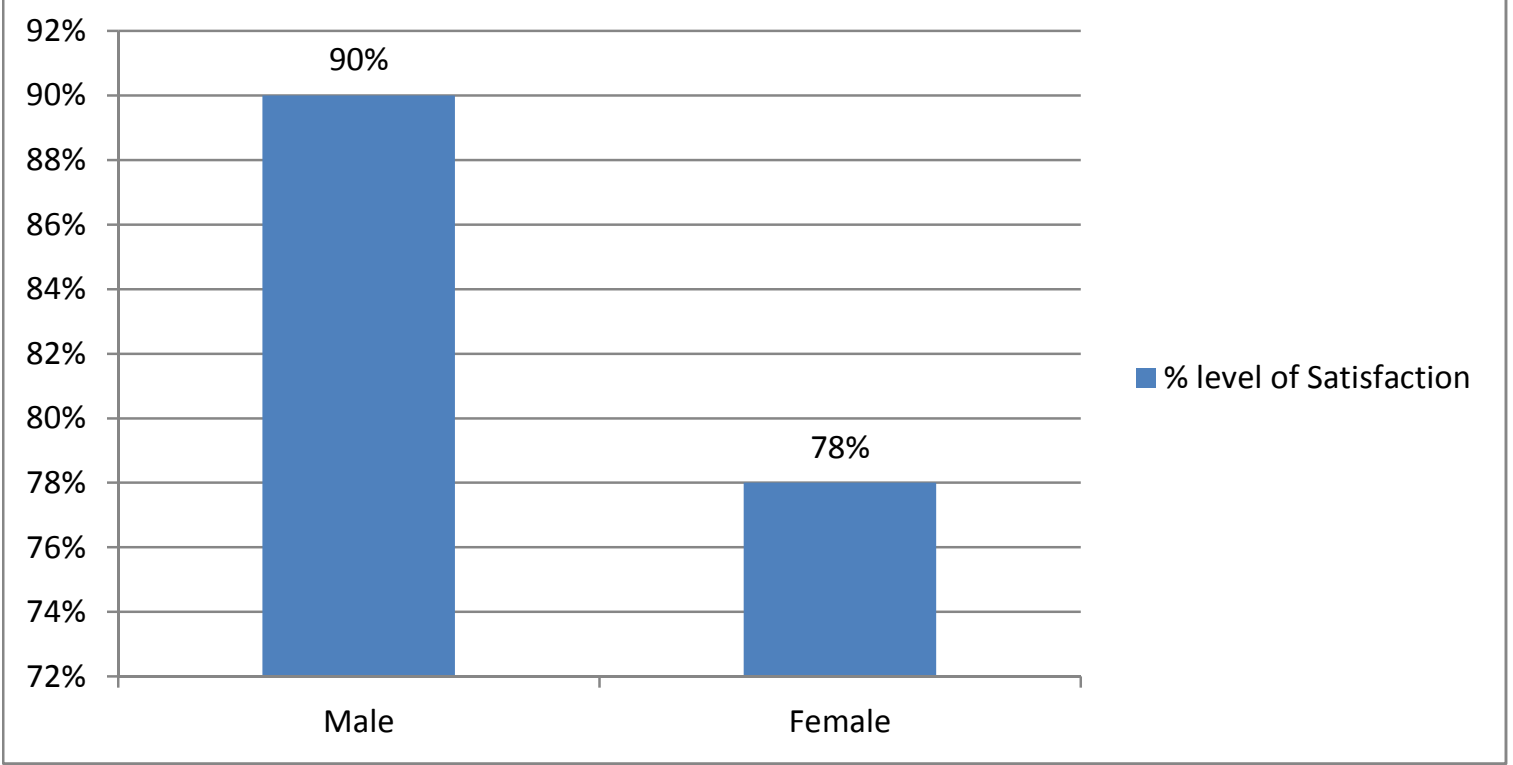

b) On the basis of Age -

Level of awareness is almost same in all age groups.

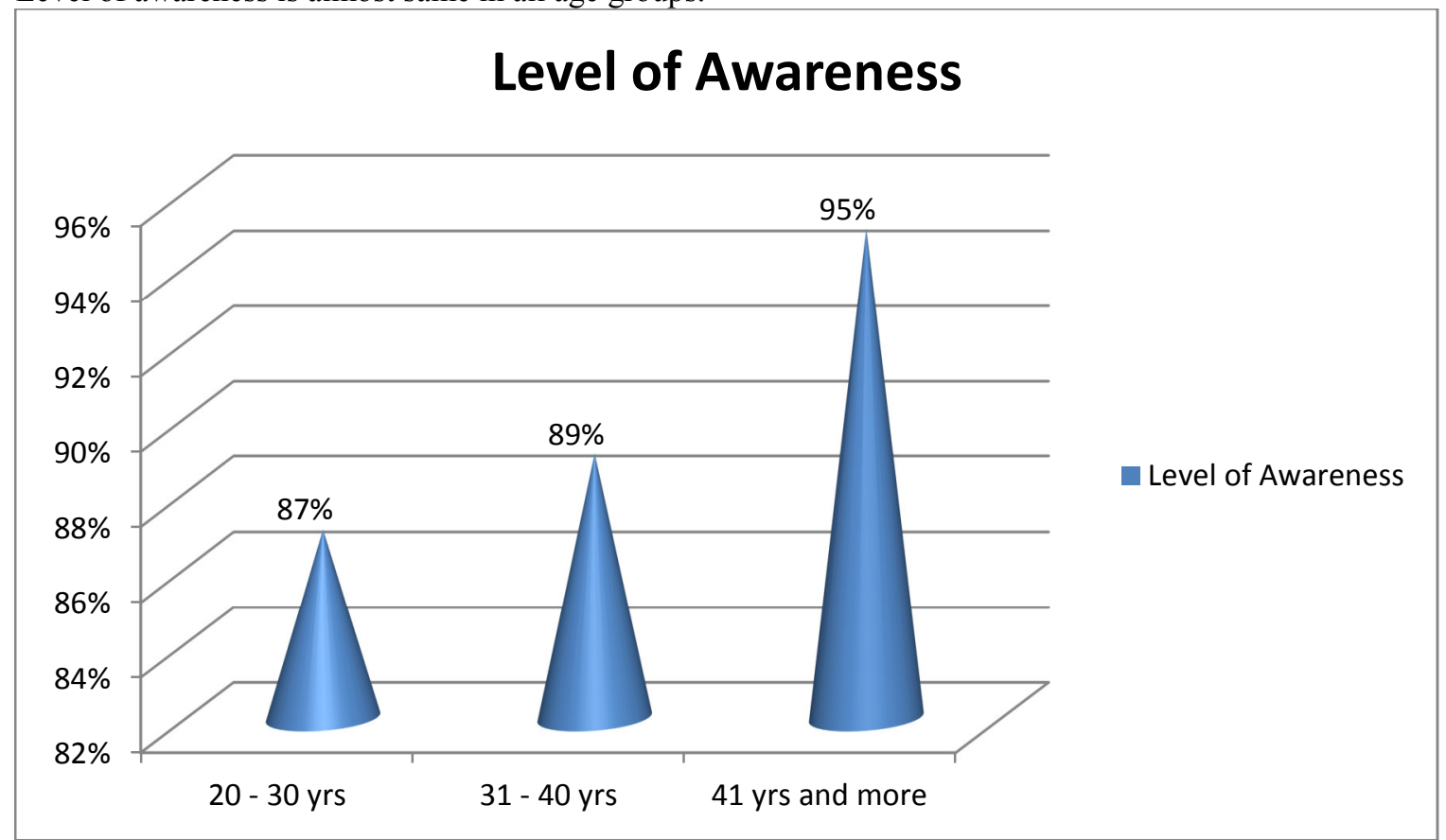

c) On the basis of tenure in organisation

With increasing tenure in the organisation the level of awareness increases. 


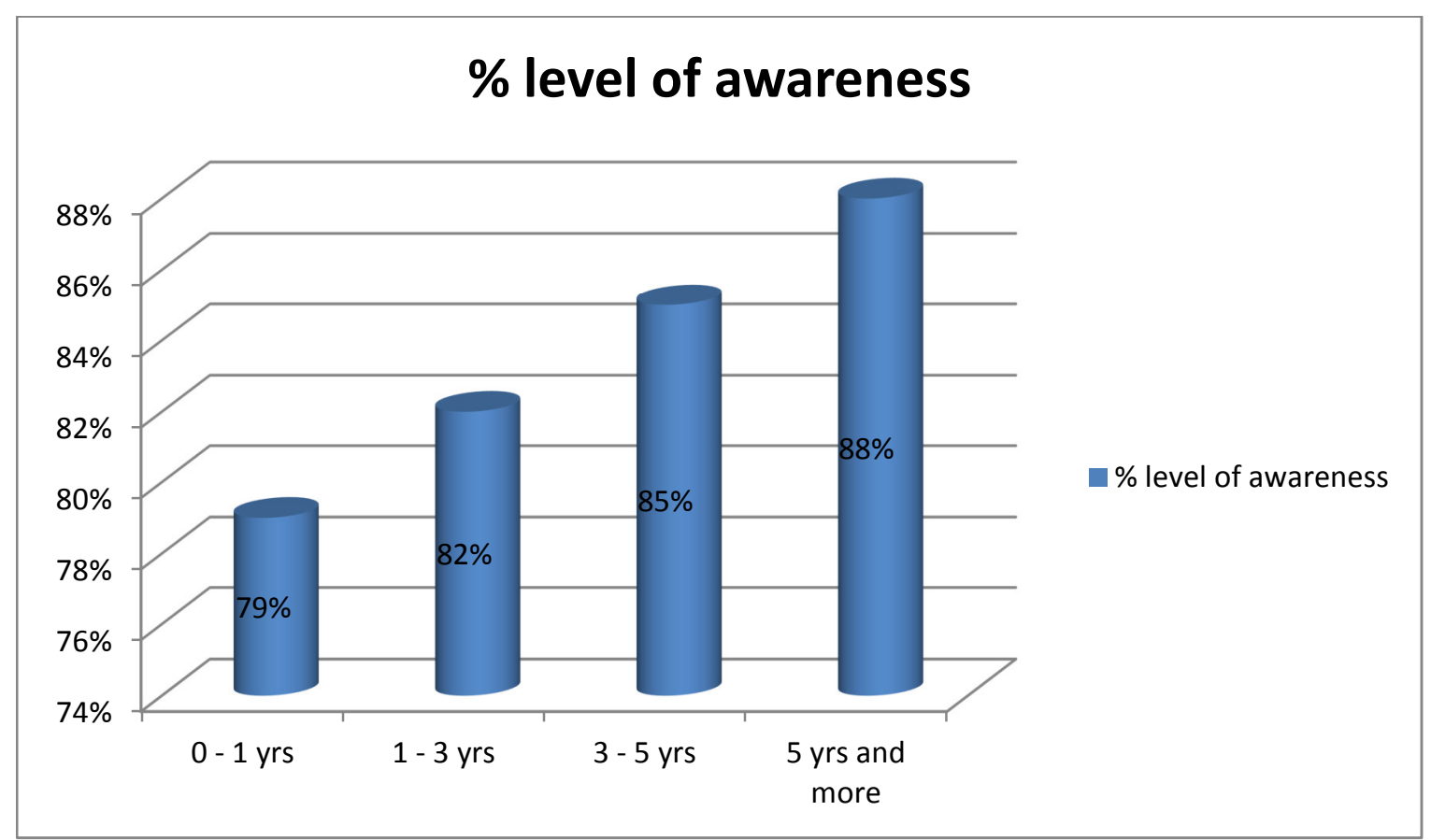

Objective 5. To make valuable suggestions regarding the EWP that employees want to be incorporated in their organisations to bridge the gap between expectations and reality

Out of the all the responses, the below listed suggestions were most prominent with respect to EWP

1. More no. of paid and unpaid holidays for medical reasons.

2. Providing better on campus facilities like extended menu in canteens, sports and activity zones etc.

3. Leisure hours after the work hours for Research and personnel growth.

4. More no. of trainings and short tern courses for updated technology status.

5. Flexi timing option for fixed no. of days in a month.

6. Better pay package in terms of variables like incentives, bonuses etc.

\section{Scope of the Study}

This study aims to analyse the current welfare facilities that are being provided to the employees. The current study analyses the satisfaction level of employees regarding various non statutory welfare programs being run by organisations. It will help the employer to find out, if the programs are designed according to the employees needs and wants, which will help to categorise different welfare programs among an intelligent activity and a wasteful expense. And hence the programs that are not required by the employees can be discontinued and the ones suggested by them can be considered for application. The study also analyses the awareness level of employees towards statutory welfare programs that are the basic rights of employees.

\section{Limitations of the study}

Despite the extensive effort the study has the following limitations.

1.IT companies have a secrecy of data and hence emails from outer sources can't be redirected, so questionnaires were to be distributed in hard copy and responses were to be fed by researcher manually .Therefore many respondents could not be contacted due to shortage of time.

2. Employees were short of time in view of the pressing job demands, and rigorous work schedules. Hence, the researcher has to persuade them for sparing time for responding to the questionnaires and interviews.

\section{References}

1. Misener, T. R., Haddock, K. S., Gleaton, J. U., \& Ajamieh, A. R. A. (1996). Toward an international measure of job satisfaction. Nursing research, 45(2), 87-91.

2. Kudchelkar, D. L. S. (1979), Aspects of Personnel Management and Industrial Relations , Excel Books, New Delhi, 10.

3. Babu K.V.S.N Jawahar, Valli S. Kalesha Masthan and Bhupathi C. (2012): Recent trends in factories welfare measures, Academisia: An International Multidisciplinary Research Journal,2(12), 252-261.

4. Joseph B.; Joseph I. and Varghese R.(2009): Labour Welfare in India, Journal of Workplace Behavioural Health, Vol. 24 (1\&2)pp: 221-242. 
5. Logasakthi K. and Rajagopal K. (2013): A study on employee health, safety and welfare measures of chemical industry in the view of Sleam region, TamilNadu (India). International Jour. Of Research in Business Management, Vol. 1 (1) pp 1 - 10.

6. Mohan Reenu and Panwar J.S. (2013) : Current trends in employee welfare schemes in Udaipur Retial Sector. International Jour. of Scientific Research Review (IJSRR) 2 (2) PP. 45-54.

7. Nanda N. and Panda J.K.: (2013): Challenges and effectiveness of industrial relation environment in Indian Industries study on Rourkela Steel Plant. Raurkela Odisha. India. International Jour. Of Financial Services and management Research Vol. 2 (6) 2013 pp. 163-174.

8. Rao T.V. (1991): Reading in Human Resource Development. Oxford \& IBH Publication New Delhi.

9. Resma S. and Basavraju M.J. (2013): Employee welfare measure in mining Industry - A study with reference to statutory welfare measures. in NMDC, Donimalai Iron ore, Mine Bellari district Karnatanka. Excel International Jour. of Multidisciplinary Management Studies (EIJMMS)Vol. 3 PP. 157-164.

10. Sabarirajan A.,Meharajan T., Arun B. (2010): A study on the various welfare measures and their impact on QWL provided by the Textile Mills with reference to Salem District, Tamil Nadu, India. Asian Jour. of Management Research. Pp. 15-24.

11. Satayanarayan M.R. and Redhi R.J. (2012): Labour welfare measure in cement industries in India. IJPSS Jour. Vol. 2 (7) PP. 257-254.

12. Shrinivas K.T. (2013): A study on employees welfare facilities adopted at Bosch Limited,Bangalore. Res. Jour. of Management Sciences Vol. 2 (12) pp. 7-11.

13. Sindhu Sailesh (2012): Role of Organization in welfare measures for employees. International Jour. of Research in IT and Management (IJRIM) Vol. 2 (9) pp. 36-40.

14. Tiwari Pankaj(2011):Impact of selected HRM practices on perceived employee performance.Global Management Journal, 2 /2011; 3(1).

15. Tiwari Usha and Tiwari Rasmi (2013): Impact of organisation culture on employee retention at Jaypee Cement Plant Rewa (M.P.). Indian Jour. of Management and Indian Business Studies. Vol.1 (1) Jan-March PP. 1-12.

16. Upadhyay Devina and Anu Gupta (2012) : Morale, welfare measure, job satisfaction : The key mantras for gaining competitive edge. International Jour. of Physical and Social Sciences. Vol. 2 (7) PP. 80-94.

17. Venugopal P., Bhaskar T. and Usha P., (2011): Employee welfare activities with respective measures in industrial sector-A study on industrial cluster at Chittor district. International Journal of Research in Commerce, It and Management, 1(6), 78-84.

18. Tyagi, B. P. (1986), Labour Economics and social welfare, Meerut: Jai Prakash Nath \& Co., pp.595-613.

19. Verma, P. (1987), Labour Economics and Industrial Relations, Tata McGraw Hill Publishing Company Limited, New Delhi, p. 381.

20. Ahuja, K.K. (1988), Labour Welfare and Social Security in Personnel Management, Kalyani publishers, New Delhi, pp. 935-947.

21. Monappa, A., \& Engineer, M. (1999). Liberalisation and Human Resource Management: Challenges for the Corporations of Tomorrow. SAGE, pp. 112.

22. Tripathi, P.C. (1988) Labour Welfare and Social Security”, Personnel Management and Industrial Relations, Sultan Chand \& Sons, New Delhi, 1998 pp 325-363.

23. Aquinas P.G, ( 2007) ,Human Resource Management, Vikas Publishing House Pvt. Ltd, New Delhi, , pp. 184-191.

24. Scott Snell and George Bohlander, "Human Resource Management" Cengage India Private Ltd, New Delhi, 2007, pp. 447-482.

25. Dessler, G. (2011), Fundamentals of human resource management ,Pearson Higher Ed.(India) Pvt Ltd., New Delhi, 2009, pp.513-546.

26. Gibson, J. L., Ivancevich, J. M., \& Donnelly, J. H. (Eds.). (1976). Readings in organizations: behavior, structure, processes. Business Publications , pp. 255-383.

27. Aswathappa, K.(2010) Human Resource Management, Tata McGraw Hill Education Private Limited, New Delhi, pp. 378-392. 